SPEAR, N. E., Hil L, W. I „ \& O'SULLIVAN, D. J. Acquisition and cxtinction after initial trials without reward. Journal of Experimental Psychology, 1965, 69, 25-29.

SPEAR, N. E. \& SPITZNER, J. H. Effect of initial nonrewarded trials: Factors responsible for increased resistance to extinction. Joumal of Experimental Psychology, 1967, 74, 525-537.

\section{NOTIS}

1. This research was supported in part by National Institute of Child Health amd Human Development Grant HD04379 to the first author.

2. This case could also be called nonanticipated reward, i.e., presumably neither reward nor nonreward is anticipated.

\title{
Stimulus novelty as a factor in the intraspecific pain-associated aggression of domesticated rats ${ }^{1}$
}

\author{
BENNETT G. GALEF, JR., McMaster \\ University, Hamilton, Ont., Canada
}

Familiar and unfamiliar pairs of male Sprague-Dawley rats were exposed to ascending and descending series of shocks of constant intensity and varying duration. It was found that, while unfamiliar pairs exhibited significantly more aggression than did familiar pairs when subjected to short-duration shocks $(.05$ and .1 sec), there was no difference between the groups at longer shock durations $1.2, .3$, and $.5 \mathrm{sec}$.

Ulrich \& Azrin (1962) have reported that previous familiarity of domestic rats does not affect the frequency of occurrence of intraspecific aggression in response to unavoidable shock. Conversely, the naturally occurring fighting behavior of both domestic (Seward, 1945) and feral (Barnett, 1963; Galef, in press) rats has been found to be affected by the previous familiarity of Ss. In their study, Ulrich and Azrin used a single duration and intensity of shock $(.5 \mathrm{sec}, 1.3 \mathrm{~mA})^{2}$ in testing the effects of $S$ familiarity on intraspecific pain-associated aggression. Wetzel, Conner, \& Levine (1967), working with 85-day postoperative septally lesioned rats and their sham-operated controls, have found a significant Group by Intensity interaction in aggression in response to shock. Whereas there was a large difference between lesion and control groups in probability of fighting at low intensities of shock, the difference was much reduced at high intensities. The present experiment was designed to test the possibility that previous familiarity of Ss might similarly affect the incidence of intraspecific aggression associated with mild shock but not with intense shock.

Because Dreyer \& Church (1968) have shown that the slope of the line describing incidence of aggression as a function of increasing intensity of shock is far steeper than that describing incidence of aggression as a function of shock duration, it was decided to use duration as an independent variable in the present experiment and to hold intensity constant. A broad range of shocks eliciting moderate frequencies of aggression were thus available for presentation.

\section{SUBJECTS}

The Ss were 40 male Sprague-Dawley rats, averaging $253 \mathrm{~g}$ at the outset of the experiment. Data from one $S$ was discarded because he showed seizures in response to painful stimulation.

\section{PROCEDURE}

The Ss were confined in pairs for either 3 or 6 weeks in small hanging cages ( $7 \times 9 \frac{1 / 2}{2} \times 7$ in.). The procedure described below was carried out twice, once for the 3-week confinement group (20 Ss) and once for the 6-week confinement group $(20 \mathrm{Ss})$. Following its period of confinement, each $S$ was placed in a 6-in.-square shockbox and exposed to two shock sessions, one with its familiar cage-mate and one with an unfamiliar $S$ from another hanging cage. Forty-eight hours separated the two shock sessions for any given $S$. Half of the Ss were shocked first in the presence of an unfamiliar partner, and half were shocked first in the presence of their familiar cage-mate.

Prior to shock initiation, each pair of Ss was allowed $3 \mathrm{~min}$ to become accustomed to the shockbox. Alternating ascending and descending series of shocks, .05, .1, .2, .3 , and $.5 \mathrm{sec}$ in duration and $1.3 \mathrm{~mA}$ in intensity, were then delivered, 12 shocks per minute, through the floor of the

Table 1

Percentage of Shock Trials on Which Fighting was Observed

\begin{tabular}{|c|c|c|c|c|c|}
\hline \multirow[b]{2}{*}{ Group } & \multicolumn{5}{|c|}{ Shock Duration (Sec) } \\
\hline & .05 & .1 & .2 & .3 & .5 \\
\hline $\begin{array}{l}3 \text { Wk. Familiar } \\
3 \text { Wk. Unfamiliar }\end{array}$ & $\begin{array}{l}.27 \\
.35^{*}\end{array}$ & $\begin{array}{l}.38 \\
.50^{*}\end{array}$ & $\begin{array}{l}.56 \\
.56\end{array}$ & $\begin{array}{l}.64 \\
.63\end{array}$ & $\begin{array}{l}.70 \\
.69\end{array}$ \\
\hline $\begin{array}{l}6 \mathrm{Wk} . \text { Familiar } \\
6 \mathrm{Wk} \text {. Unfamiliar }\end{array}$ & $\begin{array}{l}.23 \\
.43^{* *}\end{array}$ & $\begin{array}{l}.38 \\
.54^{*}\end{array}$ & $\begin{array}{l}.53 \\
.60\end{array}$ & $\begin{array}{l}.63 \\
.70\end{array}$ & $\begin{array}{l}.70 \\
.78\end{array}$ \\
\hline
\end{tabular}

$* p<.05 \quad * * 0<.01$ shockbox via a Grason-Stadler Model E1064GS shock generator and scrambler. Each pair of Ss received 20 alternating ascending and descending serjes of shocks, a total of 40 shocks of each duration.

The $\mathrm{E}$ recorded the presence or absence of fighting following each shock presentation. A fight was recorded whenever both Ss were in an upright posture and one lunged at or made contact with the other (Dreyer \& Church, 1968). The experiment was run blind so that $E$ did not know whether any given pair in the shockbox was from the same or from different hanging cages.

\section{RESULTS AND DISCUSSION}

The results are presented in Table 1. Whereas Kolmogorov-Smirnov two-sample tests showed significant differences between familiar and unfamiliar pairs in the percentage of trials on which fighting occurred at short shock duration (.05 and $.1 \mathrm{sec})$ for both the 3- and 6-week familiarization groups, there was no significant difference in percentage of fights between familiar and unfamiliar pairs using longer shock durations $(.2, .3$, and $.5 \mathrm{sec}$ ).

The data indicate that, within a limited range of aversive stimulation, opponent novelty is an important variable in determining the probability of occurrence of shock-associated intraspecific aggression. The results are in accord with those of Ulrich \& Azrin (1962) in that, using their shock parameters, no significant effect of opponent familiarity was observed.

The results-further suggest that the general importance of opponent or target variables in eliciting aggression in pain-induced aggression situations may be a function of the degree of noxious stimulation applied.

\section{REFERENCES}

BARNETT, S. A. The rat, a study in behavior. Chicago: Aldine, 1963.

DREYER, P. I., \& CHURCH, R. Shock-induced fighting as a function of the intensity and duration of the aversive stimulus. Psychonomic Science, 1968, 10, 271-272.

GALEF, JR., B. G. Aggression and timidity: Responses to novelty in feral Norway rats. Journal of Comparative \& Physiological Psychology, in press.

SEWARD, J. P. Aggressive behavior in the rat. Journal of Comparative $\&$ Physiological Psychology, 1945, 38, 175-197.

ULRICH, R. E., \& AZRIN, N. H. Reflexive fighting in response to aversive stimulation. Joumal of the Experimental Analysis of Behavior, 1962, 5, 511-520.

WETZEL, A. B., CONNER, R. L., \& LEVINE, S. Shock induced fighting in septal lesioned rats. Psychonomic Science, 1967, 9, 133-134. NOTES

1. This research was supported by Grants AP307 and APA0307 of the National Research Council of Canada. Susan McLellan performed the experimental testing.

2. Ulrich, R. E., personal communication. 